\title{
WestVirginiaUniversity
}

THE RESEARCH REPOSITORY @ WVU

West Virginia Agricultural and Forestry Experiment

Davis College of Agriculture, Natural Resources

Station Bulletins

And Design

$1-1-1899$

\section{Whole corn compared with corn meal for fattening hogs}

\author{
J. H. Stewart
}

Horace Atwood

Follow this and additional works at: https://researchrepository.wvu.edu/ wv_agricultural_and_forestry_experiment_station_bulletins

\section{Digital Commons Citation}

Stewart, J. H. and Atwood, Horace, "Whole corn compared with corn meal for fattening hogs" (1899). West Virginia Agricultural and Forestry Experiment Station Bulletins. 59.

https://researchrepository.wvu.edu/wv_agricultural_and_forestry_experiment_station_bulletins/59 @ WVU. It has been accepted for inclusion in West Virginia Agricultural and Forestry Experiment Station Bulletins by an authorized administrator of The Research Repository @WVU. For more information, please contact ian.harmon@mail.wvu.edu. 
Digitized by the Internet Archive in 2010 with funding from

Lyrasis Members and Sloan Foundation 


\title{
WEST VIRGINIA
}

\section{AGRICULTURAL EXPERIMENT STATION, \\ MORGANTOWN, W. VA.}

Bulletin 59.

JUNE, 1899.

\section{Whole Corn Compared With Corn Meal for Fattening Hogs.}

\author{
By J. H. Stewart axi Horace Atwood
}

[The Bulletins and Reports of this Station will be mailed free to any citizen of West Virginia upon written application. Address Director of Agricultural Experiment Staltion, Morgantown W. Va.] 
THE REGENTS OF THE WEST VIRGINIA UNIVERSITY.

NAME OF REGENTS.

Hon. George C. Sturgiss,

Hon. JaMES F. Brown,

Hon. A. H. Kunst,

Hon. Richard Randolph McMahon,

Hon. James M. LeE,

Hon. James M. Hamill,

Hon. John A. Campbelt,

Hon. W. E. Powell,

Hon. P. C. Eastham,
P. O. ADDRESS.

Morgantown

Charleston

Weston.

- Harper's Ferry

- Lewisburg

- Welch

New Cumberland

- Parkersburg

Pt. Pleasant

\section{STATION COMMITTEE.}

Genrge C. Sturgiss.

JAMES L. HAMILL.

President Regents,

President University,

Treasurer,

Auditor,
JaMes F. Brown.

\section{Jame F. Brown.}




\section{WHOLE CORN COMPARED WITH CORN MEAL AS A FOOD FOR FATTENING HOGS.}

EXPERIMENTS IN 1897.

The practical question often arises whether it will pay a farmer to go to the trouble and expense of grinding his corn before feeding it to his hogs. Even though somewhat more pork may be prodnced by feeding corn meal, yet this increased gain in weight may be obtained at a financial loss, and it may be better to feed the whole grain, even though less pork is produced. To answer this question a series of experiments were planned, the first of which is here reported.

Nirie hogs about six and one-half months old were availaible for the experiment. All of them had previously been fed on a well balanced ration of ground feed, and were in good condition when the test began. They were divided into three lots of three each. The pigs in lots I and If were from a litter resulting from a cross of a Poland China boar on a Duroc Jersey sow. The pigs in lot III were a cross of the same boar on a Berkshire sow.

The hogs were fed for two periods of two weeks each and thea butchered. The following table gives the werght of the individual hogs at the beginning of each period and the gain made: 
TABLE I. FIRST PERIOD-TWO WEEKS.

\begin{tabular}{|c|c|c|c|c|c|c|}
\hline \multirow{5}{*}{$\Phi$} & \multicolumn{2}{|c|}{$\begin{array}{l}\text { Lot I. } \\
\text { Whole Corn. }\end{array}$} & \multicolumn{2}{|c|}{$\begin{array}{l}\text { Lot II. } \\
\text { Corn Meal. }\end{array}$} & \multicolumn{2}{|c|}{$\begin{array}{l}\text { Lot III. } \\
\text { Corn Meal. }\end{array}$} \\
\hline & Wuight. & Gain. & Weight. & Gain. & Weight. & Gain. \\
\hline & 248.6 & 14.4 & 247.0 & 42.0 & 164.3 & 31.7 \\
\hline & 253.5 & 20.5 & 201.6 & 37.4 & 163.3 & 35.7 \\
\hline & 215.5 & 12.5 & 235.5 & 44.5 & 160.0 & 32.0 \\
\hline Total. & 717.6 & .47 .4 & 684.1 & 123.9 & 487.6 & 99.4 \\
\hline
\end{tabular}

SECOND PERIOD-TWO WEEKS.

\begin{tabular}{|c|c|c|c|c|c|c|}
\hline & \multicolumn{2}{|c|}{$\begin{array}{l}\text { Lot } 1 \text {. } \\
\text { Whole Corn. }\end{array}$} & \multicolumn{2}{|c|}{$\begin{array}{l}\text { Lot Il. } \\
\text { Corn Neal. }\end{array}$} & \multicolumn{2}{|c|}{$\begin{array}{c}\text { Lot Ill. } \\
\text { Corn Meal. }\end{array}$} \\
\hline & Weight. & Gain. & Weight. & Gain. & Weight. & Gain. \\
\hline & 263.0 & 32.0 & 289.0 & 37.5 & 196.0 & 18.0 \\
\hline & 274.0 & 39.0 & 239.0 & 14.0 & 199.0 & 21.0 \\
\hline & 228.0 & 23.0 & 280.0 & 24.5 & $19 \ddot{0} .0$ & 23.0 \\
\hline 'Total. & 765.0 & 94.0 & 808.0 & 76.0 & 587.0 & 62.0 \\
\hline $\begin{array}{l}\text { Total gain } \\
\text { for both } \\
\text { Periods. }\end{array}$ & & 141.4 & & 199.9 & & 161.4 \\
\hline
\end{tabular}

It is seen from an inspection of this table that the lot fed whole corn durng the first period gained only about one-third as much as lot II which was fed corn meal, while in the second period the lot fed whole corn gained more than either of the other lots. These seemingly contradictory results may have been due in part to the fact that lot I, having been previously ferl on ground feed, did not take kindly to its new ration of dry, hard corn, and only later became accustomed to it; also, the evening before the hogs were weighed, to determine the amount of gain made dnring the first period, lot I had been fed more corn than was consumed during the night, and as some still remained in the trough in the morning, they were not fed any more by the foreman. Hence, the actual gain made by the hogs fed corn during the first period is somewhat greater than is shown by the table. As the conclusions are based, however, on the average of the two periods, the final results are not altered.

The following table shows the amount of grain consumed by the different lots during each of the two periods. The hogs were fed three times each day, all that they would consume: 
WHOLE CORN COMPARED WITH CORN MEAL FOR FATTENING HOGS. 41 TABLE II. FIRST PERIOD--TWO WEEKS.

\begin{tabular}{|c|c|c|c|}
\hline & $\begin{array}{c}\text { Lot I. } \\
\text { Whole Corn }\end{array}$ & $\begin{array}{c}\text { Lot II. } \\
\text { Corn Meal }\end{array}$ & $\begin{array}{l}\text { Lot III. } \\
\text { Corn Meal. }\end{array}$ \\
\hline Consumed uf grain & 413.30 & 477.00 & 396.40 \\
\hline ed in live weight ....... & 47.40 & 123.90 & 99.40 \\
\hline Pound feed for one pound gain. & 8.71 & 3.84 & $3.9 s$ \\
\hline
\end{tabular}

SECOND PERIOD-TWO WEEKS.

\begin{tabular}{|c|c|c|c|}
\hline & $\begin{array}{l}\text { Lot I. } \\
\text { Whole Corn }\end{array}$ & $\begin{array}{l}\text { Lot } 11 . \\
\text { Corn Meal }\end{array}$ & $\begin{array}{c}\text { Lot III. } \\
\text { Corn Meal. }\end{array}$ \\
\hline Consumed of grain & 406.00 & 474.00 & 352.00 \\
\hline Gained in live weight...... & 94.00 & 76.00 & 62.00 \\
\hline Pounds feed for one pound gain.. & 4.32 & 6.23 & 5.68 \\
\hline
\end{tabular}

FIRST AND SECOND PERIODS.

\begin{tabular}{|c|c|c|c|}
\hline & $\begin{array}{c}\text { Lot I. } \\
\text { Whole Corn }\end{array}$ & $\left|\begin{array}{cc}\text { Lot } & \text { II. } \\
\text { Corn } & \text { Meal }\end{array}\right|$ & $\begin{array}{cc}\text { Lot III. } \\
\text { Corn Meal. }\end{array}$ \\
\hline Consumed of $g$ & 819.30 & 951.00 & 748.40 \\
\hline in live weight.......... & 141.40 & 199.90 & 161.40 \\
\hline Pounds feed for one pound gain. & 5. 79 & 4.75 & 4.63 \\
\hline
\end{tabular}

During the first period lot II produced a pound of gain on less than half the feed that was required by lot $I$, while in the seconrl period these conditions were reversed and lot I produced a pound of gain more economically. If we consider the average of the two periods we find that lot I, fed whole corn, required 5.79 pounds of feed for one pound of gain, while lot II required 4.75 pounds, and lot III 4.63 pounds. It would consequently appear that if corn meal were as cheap as whole corn that it would be better to feed meal.

The difference in the cost of these two feeding stuffs depends on circumstances. If a farmer lives, say four or five miles from a mill, it is worth about $\$ 2.00$ to take a luad of 40 bushels of shelled corn to the mill and draw it back home. With corn at 40 cents per bushel it wonld cost then just abont one-eighth of the value of the corn to haul it. The miller is also entitled by law to one-eighth of the corn for grinding the remainder, and consequently it would cost many farmers one quarter of their corn to get it ground.

The lot which was fed whole corn consumed during the two feeding periods 819.3 pounds of corn, and gained 141.4 pounds in weight. If this corn had been ground, allowing one-quarter for 
hauling and grinding, there would have been 614.5 pounds of meal. Now, 951 pounds of meal fed to lot II produced 199.9 pounds of gain; consequently one pound of meal produced .2102 poutuds of gain, and 614.5 pounds of meal would have produced 129.1 pounds increase in live weight. The whole corn, however, actually produced 141.4 pounds of increase, hence, there was a gain from feeding the whole corn of the difference between 141.4 pounds actually gained, and 129.1 pounds which would have been gained had the corn been ground into meal and then fed. This difference, then, of 12.3 pounds of increase in live weight is in favor of feeding the whole corn, and we may assume that there would have been a greater difference in favor of the corn fed lot had they not suddenly been changed at the beginning of the experiment from a ground feed ration to whole corn which they did not at first relish.

As it is of interest in this connection to bring together the results of all of the experiments which have been performed in this country to determine whether it is better practice to feed corn or corn meal the following table has been compiled showing the more important details of these axperiments : 
WHOLE CORN COMPARED WITH CORN MEAL FOR FATTENINF HOGS, 43

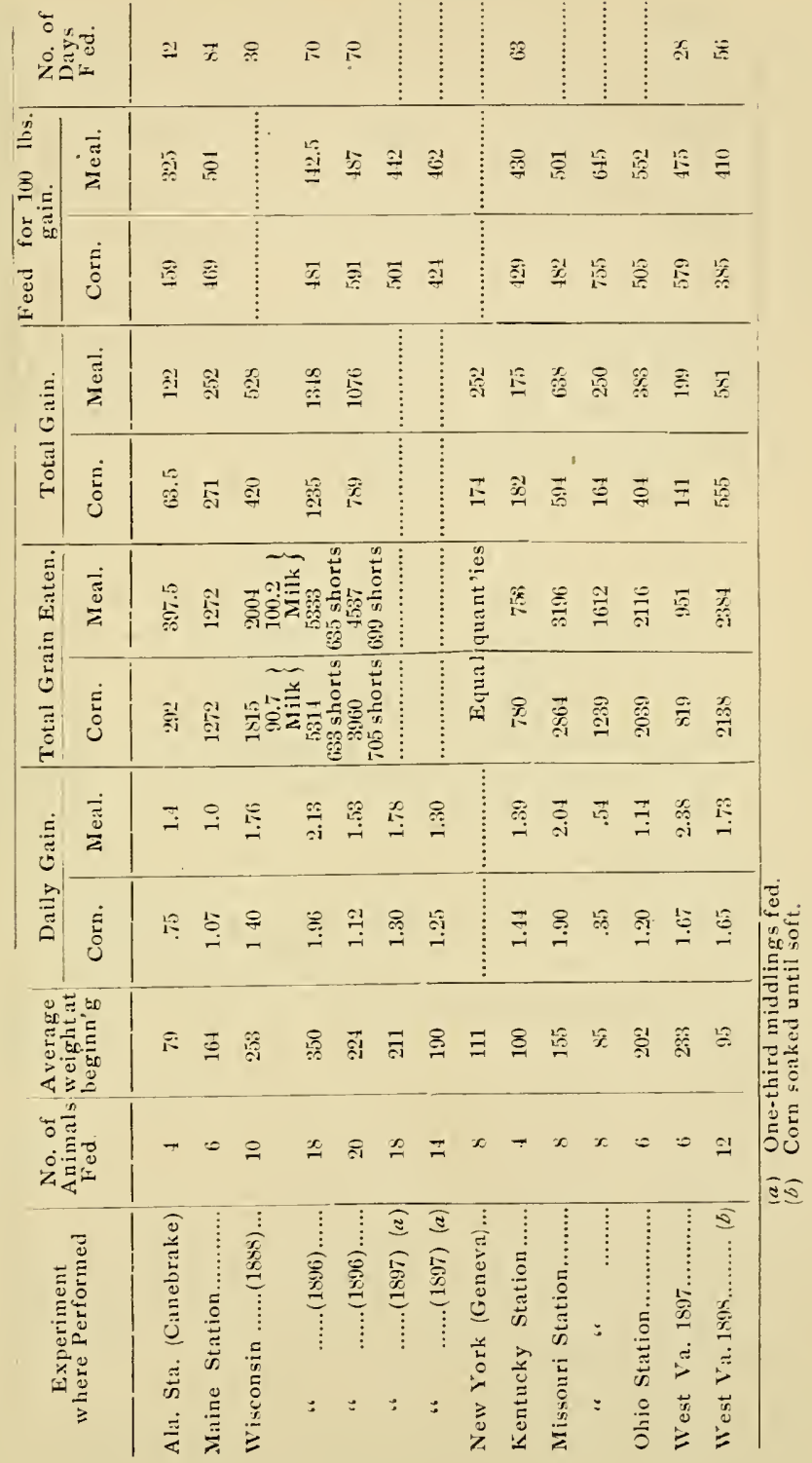


The average of the twelve experiments in which the amount of feed required for 100 pounds gain in live weight is given, shows that 505 pounds of corn, and 472.9 pounds of corn meal were required for 100 pounds of gain, or in other words in these experiments it required abont 6 per cent less corn to produce 100 pounds gain when it was ground than when it was fed unground.

The average of these different experiments and our own results indicate that unless a farmer is located very close to a mill, or has one upon his own farm that at present prices it will not pay to grind corn for hogs.

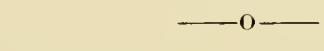

\section{SOAKING CORN FOR HOGS.}

EXPERIMENTS IN 1898.

Nearly all of the pork which is produced in the United States is derived from corll-fed hogs, yot very few experiments have ever heen performed to determine the best and most economical way of feeding corn.

The following experiment was planned to determine whether soaking corn in water affects in any way its food value.

Poland-China-Duroc-Jersey and Poland-China-Berkshire cross bred pigswere used in the experiment. They were divided into two lots similar in respect to size, breed and sex.

From a car load of western corn sufficient was procured for the experiment. A portion of this was ground into meal and the remaining shelled corn was soaked in water. as needed, until the grains were soft. The meal was mixed with water hefore being fed. No attempt was made to feed the same quantities of meal and soaked corn, but each lot was fed all that it would eat up clean.

The following tables give the weights of the different animals at the begining of the experiment and at the end of each 14 day period, together with other details of the experiment: 
WHOLE CORN COMPARED WITH CORN MEAL FOR FATTENING HOGS, 45 WHOLE CORN LOT.

\begin{tabular}{|c|c|c|c|c|c|c|}
\hline 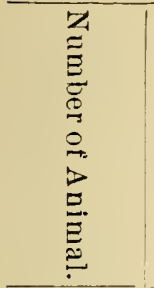 & 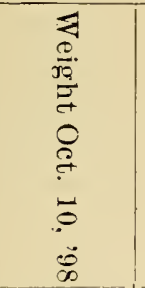 & 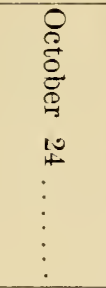 & 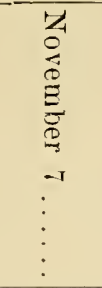 & 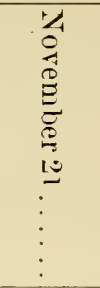 & 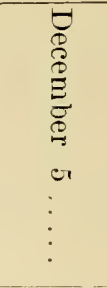 & $\begin{array}{l}\text { 田 } \\
\stackrel{0}{\Xi} \\
\vdots \\
\vdots \\
\vdots \\
\vdots \\
\vdots\end{array}$ \\
\hline 69 & & & & & & \\
\hline $\begin{array}{c}\text { a. c. } \\
43\end{array}$ & 96.5 & 131.6 & 149. & 178.5 & 199.5 & . \\
\hline $\begin{array}{c}\text { a. c. } \\
39\end{array}$ & 80.5 & 107.1 & 119. & 136 & 150.5 & $\ldots \ldots$ \\
\hline a. $\frac{d}{68}$ & 96. & 123.5 & 140.5 & 166 & 184.5 & $\ldots$ \\
\hline $\begin{array}{c}\text { a. d. } \\
32\end{array}$ & 102. & 135. & 152.5 & 180.5 & 202 & $\cdots \cdots$ \\
\hline $\begin{array}{c}\text { b. c. } \\
71\end{array}$ & 106. & 141.2 & 164. & 195 & 212 & \\
\hline $\begin{array}{l}\text { b. d. } \\
\text { Total }\end{array}$ & 88.5 & 114.6 & 131. & 157 & 176 & $\ldots$. \\
\hline Weight. & 569.5 & 753.0 & 856.0 & 1013. & 1124.5 & $\ldots \ldots \ldots$ \\
\hline \multicolumn{2}{|c|}{ Total Gain .. } & 183.5 & 103.0 & 157 & 111.5 & 555 \\
\hline \multicolumn{2}{|c|}{ F'ood Consumed... } & 527 & 489 . & 576 & $5+6$ & 2138 \\
\hline
\end{tabular}


CORN MEAL LOT.

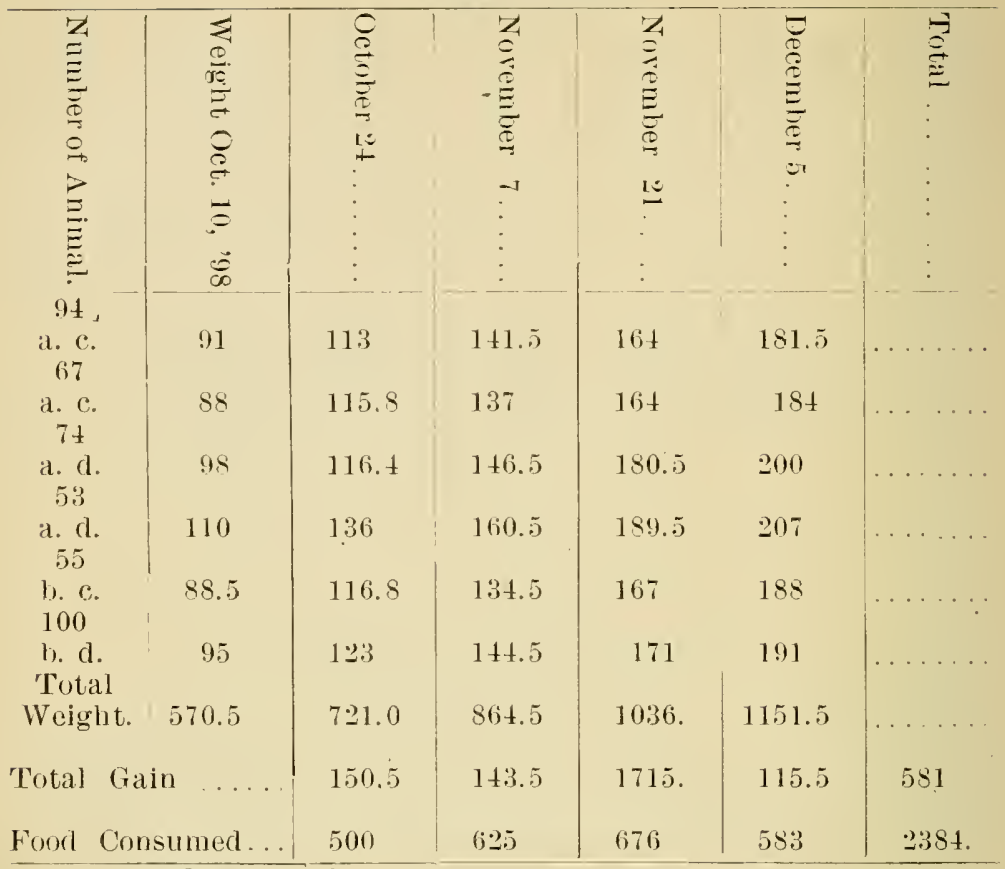

a-Sow.

b-Barrow.

c-Poland-China-Durac-Jersey.

d-Poland-China-Berkshire.

The lot fed soaked corn consumed 2138 pounds of corn and gained in weight 555 pounds. For 100 pounds in live weight they consequently required 385 pounds of corn. The lot fed. on corn meal required 410 pounds of meal for 100 pounds gain, therefore the soaked corn produced the more economical gain, to say nothing about the extra expense of grinding the corn.

As very few experiments have ever been performed to determine the effect of soaking grain upon its digestibility, the subject requires further study. The result of our experiment indicates, however, that it is good practice. 


\section{NOTIOE.}

Applications for bulletins of this Station should be addressed to the Director of the West Virginia Agricultural Experiment Station, Morgantown, W. Va.

(The bulletins named below are available for distribution.)

No. 4. The Creamery Industry; Its Adaptability to West Virginia.

No. 5. The Selection of Milch Cows.

No. 6. Six Months' Experience in Kunning a Creamery; Inproved Process of Handling Cream and Churning.

No. 12. The Canada Thistle.

No. 14. Farm and Garden Insects and Experiments with Remedies; Notes of the Season.

No. 15. Raspberry Gouty-Gall Beetle.

No. 16. Yellow Locust, Insect Ravages upon.

No. 17. Black Spruce, Insect Ravages.

No. 19. Your Weeds and Your Neighbors's, Part I. Weeds as Fertilizers.

No. 20. Potato Culture and Fertilizers. Tests of Some Varieties of Tomatoes.

No. 21. Injurious Insects and Plant Diseases.

No. 25. Plat Experiments with Commercial Fertilizers, on. Wheat.

No. 27. Notes on Pruning.

No. 28. PJat Experiments with Commercial Fertilizers on Corn.

No. 29. Experiments with Potatoes at the Station. Experiments on Corn at the Out-Stations.

No. 30. Address and Notes on Sheep.

No. 33. Sub-Irrigation in the Green House.

No. 38. Potato Blight, Potato Scab.

No. 40. Commercial Fertilizers.

No. 42. Vegetables.

No. 43. When, Why, What and How to Spray.

No. 44. Practical Entonology.

Special Bulletin No. 2. Proceeding connected with the celebration upon the completion of the Station Building and the organization of the Sheeploreeders and Wool-Growers' Association and the State Horticultural Society.

Third Annual Report, 1890.

No. 51. Commercial Fertilizers, Jan. '98.

No. 52. Strawberries.

No. 53. Commercial Fertilizers, Dec. '98.

No. 54. Nursery Hints.

No. 55. Sugar Beet Investigation. 
